\title{
Gram-Negative Bacterial Lipopolysaccharide Stimulates Activin A Secretion from Human Amniotic Epithelial Cells
}

\author{
Yumiko Abe, ${ }^{1}$ Risa Marukawa, ${ }^{2}$ Nami Tsuru, ${ }^{3}$ Maki Sato, ${ }^{4}$ Hiroko Matsuda, ${ }^{5}$ \\ Hisanobu Sadakata, ${ }^{5}$ Takashi Kameda, ${ }^{5}$ and Takashi Minegishi ${ }^{5}$ \\ ${ }^{1}$ Department of Laboratory Sciences, Graduate School of Health Sciences, Gunma University, 3-39-22 Showa, Maebashi, \\ Gunma 371-8514, Japan \\ ${ }^{2}$ Kuki General Hospital, Kuki, Saitama 346-0021, Japan \\ ${ }^{3}$ Miyazaki Prefectural Nobeoka Hospital, Nobeoka, Miyazaki 882-0835, Japan \\ ${ }^{4}$ Yokota Maternity Hospital, Maebashi, Gunma 371-0031, Japan \\ ${ }^{5}$ Department of Obstetrics and Gynecology, Graduate School of Medicine, Gunma University, 3-39-22 Showa, Maebashi, \\ Gunma 371-8511, Japan
}

Correspondence should be addressed to Yumiko Abe; abe@gunma-u.ac.jp

Received 29 April 2013; Accepted 1 July 2013

Academic Editor: Maria L. Dufau

Copyright (C) 2013 Yumiko Abe et al. This is an open access article distributed under the Creative Commons Attribution License, which permits unrestricted use, distribution, and reproduction in any medium, provided the original work is properly cited.

\begin{abstract}
Activin A is involved in inflammation. The present study was performed to clarify if lipopolysaccharide, a component of Gramnegative bacteria, stimulates activin A secretion from human amniotic epithelial cells and to determine if activin A plays a role in amnionitis. Fetal membranes were obtained during elective cesarean sections performed in full-term pregnancies of patients without systemic disease, signs of premature delivery, or fetal complications. Amniotic epithelial cells were isolated by trypsinization. The activin A concentrations in the culture media were measured by enzyme-linked immunosorbent assay, and cell proliferation was assessed by 5-bromo-2'-deoxyuridine incorporation. Amniotic epithelial cells secreted activin A in a cell density-dependent manner, and lipopolysaccharide $(10 \mu \mathrm{g} / \mathrm{mL})$ enhanced the secretion at each cell density. Lipopolysaccharide $(10-50 \mu \mathrm{g} / \mathrm{mL})$ also stimulated activin A secretion in a dose-dependent manner. Contrary to the effect of activin A secretion, lipopolysaccharide inhibited cell proliferation in amniotic epithelial cells. The present study suggests that lipopolysaccharide stimulation of activin A secretion may be a mechanism in the pathogenesis of amnionitis.
\end{abstract}

\section{Introduction}

Activins, which were first identified as stimulators of FSH secretion, are pluripotent growth factors in the TGF-beta superfamily [1]. Among the many functions of activins, the involvement of activin A in inflammation has been noted [16]. The administration of lipopolysaccharide (LPS), a Gramnegative bacterial cell wall component, prominently increases the serum activin A level in sheep and mice $[7,8]$. Activin A levels in the circulation were higher in mice that died than in mice that survived after the administration of a sublethal dose of LPS [8]. Furthermore, cotreatment with follistatin, which neutralizes activin by binding to it, increased the survival rate of LPS-treated mice [8]. The activin A release in mice depends on a signaling cascade through Toll-like receptor 4 (TLR4), a receptor for LPS [8].

Serum activin A concentrations are elevated in patients with septicemia [9]. During pregnancy, serum activin A concentrations increase [10] and activin A dimers and activin beta-A subunits are detected in trophoblasts and amniotic epithelial cells (AEC) in the human placenta [11, 12]. The expression of activin beta-A subunit mRNA in fetal membranes increases during labor [13]. Activin A concentrations in amniotic fluid are higher in women with preterm labor than in women without preterm labor at the same stage of gestation [13]. Activin A concentrations in amniotic fluid are also elevated in women with intra-amniotic infection [14]. 
The notion that activin $\mathrm{A}$ is involved in chorioamnionitis is also supported by in vitro studies. Activin A secretion from gestational tissues and cells is stimulated by inflammatory cytokines. Tumor necrosis factor- $\alpha$ (TNF- $\alpha$ ) stimulates activin A production in explant cultures of human amnion, and choriodecidua [15], and cultured human AEC [16]. Interleukin (IL)-1 $\beta$ also stimulates activin $\mathrm{A}$ production in the amnion, choriodecidua [15], and AEC [16]. Activin A modulates the secretion of IL-6, IL-8, and prostaglandin E2 in explant cultures of human amnion and choriodecidua [17].

Compared to the effects of TNF- $\alpha$ and IL- $1 \beta$, the effect of LPS on activin A secretion from human AEC is inconsistent, despite the expression of functional TLR4 in human AEC [18]. Rosenberg et al. reported that LPS stimulated activin A release from cultured amniochorion explants but not from placental villous tissue [14]. On the other hand, Keelan et al. reported that LPS did not affect activin A secretion from amnion explant cultures [15]. Since the amnion is an avascular tissue and AEC are located in the innermost layer of the amnion, secretions of AEC must be directly released into the amniotic fluid and affect the fetus. The present study was performed to determine if LPS stimulates activin A secretion from AEC and to verify the notion that activin A is involved in amnionitis.

\section{Materials and Methods}

2.1. Reagents. LPS that was phenol extracted from E. coli O26 was purchased from Paesel \& Lorei GmbH (Hanau, Germany) (catalogue no. 100976, Lot. 15303).

2.2. AEC Culture. With the permission of the Institutional Review Board of Gunma University Hospital and the written informed consent of the patients, we obtained fetal membrane samples during elective cesarean sections performed on four patients with full-term pregnancies who did not have any systemic disease, signs of premature delivery, or fetal complications. AEC were prepared as previously reported [19] on the basis of the method established by Okita et al. [20] with slight modifications. Briefly, the chorion was removed from amnion mechanically, and the amnion was washed thoroughly with phosphate-buffered saline. The removal of the chorion was ascertained by using hematoxylin/eosin-stained paraffin sections of amnions. The amniotic membrane was cut into pieces and incubated in $170 \mathrm{~mL}$ of Krebs-Ringer solution containing $0.15 \%$ trypsin, $1.26 \mathrm{mg} / \mathrm{mL}$ sodium bicarbonate, $25 \mathrm{mM}$ HEPES, $100 \mu \mathrm{g} / \mathrm{mL}$ streptomycin, and $0.5 \mu \mathrm{g} / \mathrm{mL}$ amphotericin $\mathrm{B}$ at $37^{\circ} \mathrm{C}$ in a spinner flask. The liberated cells were decanted at $30 \mathrm{~min}$ intervals, and the incubation was performed seven times with freshly made trypsin solution. Each fraction of dispersed cells was centrifuged and resuspended in DME/Ham's F12 medium supplemented with $10 \%$ fetal bovine serum (FBS), $100 \mu \mathrm{g} / \mathrm{mL}$ streptomycin, and $0.5 \mu \mathrm{g} / \mathrm{mL}$ amphotericin B. The first fraction was discarded. The cell viability of the remaining fractions was determined by trypan blue exclusion, and the fractions with viabilities of at least $80 \%$ were pooled. Cells in

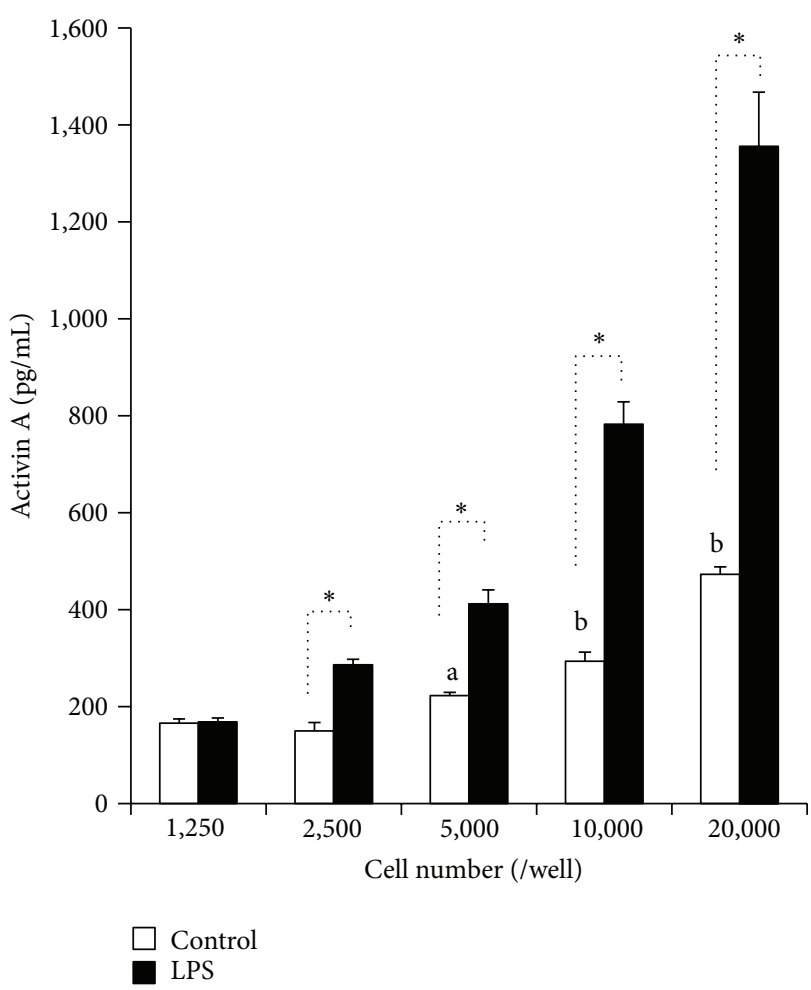

FIGURE 1: Effect of LPS on activin A secretion at various densities of AEC. Human AEC were seeded in 96-well microplates at densities of $1,250,2,500,5,000,10,000$, and 20,000 cells per well in $200 \mu \mathrm{L}$ of DME/Ham's F12 medium supplemented with 10\% FBS, $100 \mu \mathrm{g} / \mathrm{mL}$ streptomycin, and $0.5 \mu \mathrm{g} / \mathrm{mL}$ amphotericin B. Either LPS $(10 \mu \mathrm{g} / \mathrm{mL})$ or vehicle (control) was added to each well. After $96 \mathrm{~h}$ of culture, activin A in the medium was measured. Closed rectangles: LPS. Open rectangles: control. The results from the quadruplicate assay are shown as the mean \pm SE $(n=4)$. ${ }^{\mathrm{a}} P<0.05$ compared with the control value at 1,250 cells/well. ${ }^{\mathrm{b}} P<0.01$ compared with the control value at 1,250 cells/well. ${ }^{*} P<0.01$ compared with the control value at each cell density.

$200 \mu \mathrm{L}$ of medium were seeded in each well of 96-well plates and cultured in a humidified atmosphere containing $5 \% \mathrm{CO}_{2}$ $95 \%$ air at $37^{\circ} \mathrm{C}$. These cells were used for measuring activin $\mathrm{A}$ and cell proliferation.

2.3. Activin A ELISA. Activin A concentrations in culture medium were measured by using an activin A assay kit (Oxford Bio-Innovations, Oxfordshire, UK) according to the manufacturer's instructions. The samples, which were pretreated with sodium dodecylsulfate and hydrogen peroxide, were added along with assay diluent to microwells coated with a monoclonal antibody specific for the beta-A subunit of activin. After $1 \mathrm{~h}$ of incubation, biotinylated monoclonal antibody for the beta-A subunit of activin was added and incubated overnight. The following day, wells were washed and streptavidin-alkaline phosphatase solution was added. After $1 \mathrm{~h}$ of incubation, the wells were washed and incubated with substrate solution for $2 \mathrm{~h}$. Then, amplifier solution was added, and the absorbance at $490 \mathrm{~nm}$ was measured. 


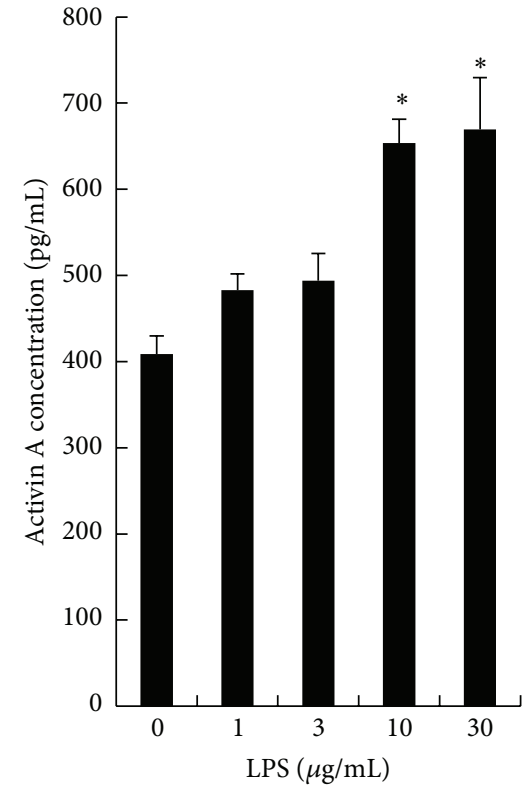

(a)

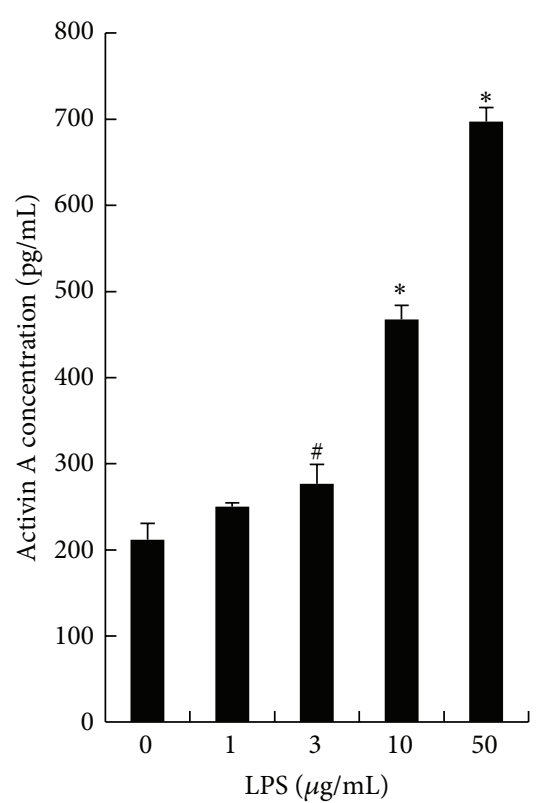

(b)

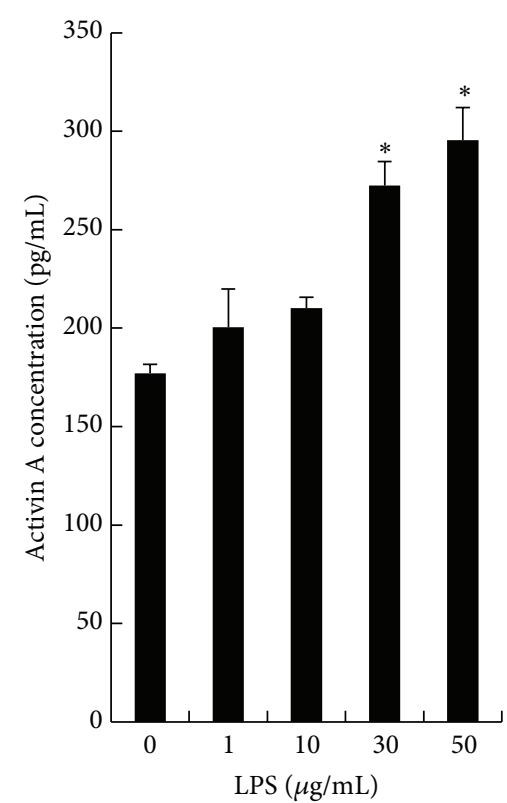

(c)

FIGURE 2: Dose-dependent effects of LPS on activin A secretion in three independent experiments. Fetal membranes were obtained from three patients, and AEC from each patient were cultured independently at a density of 20,000 cells per well in DME/Ham's 12 medium supplemented with $10 \% \mathrm{FBS}, 100 \mu \mathrm{g} / \mathrm{mL}$ streptomycin, $0.5 \mu \mathrm{g} / \mathrm{mL}$ amphotericin B, and various concentrations of LPS for $96 \mathrm{~h}$. Each independent result is shown in panels (a), (b), and (c). The results are shown as the mean $\pm \mathrm{SE}(n=4) .{ }^{\#} P<0.05$ compared with the control (LPS; $\left.0 \mathrm{ng} / \mathrm{mL}\right)$ value. ${ }^{*} \mathrm{P}<0.01$ compared with the control (LPS; $0 \mathrm{ng} / \mathrm{mL}$ ) value.

2.4. Cell Proliferation Assay. Cell proliferation was measured by assessing 5-bromo-2' -deoxyuridine (BrdU) incorporation by using a Cell Proliferation ELISA, BrdU (colorimetric) kit (Roche Diagnostics, Mannheim, Germany). The assay was performed in accordance with the manufacturer's instructions. Cells were seeded into 96-well microplates with or without LPS. After a $96 \mathrm{~h}$ incubation, $20 \mu \mathrm{L}$ of $100 \mu \mathrm{M}$ BrdU solution was added to each well containing $200 \mu \mathrm{L}$ of medium, and the cells were reincubated for another $24 \mathrm{~h}$. The culture medium was removed, the cells were fixed, and the DNA was denatured. The cells were then incubated with mouse anti-BrdU monoclonal antibody conjugated to peroxidase at room temperature for $90 \mathrm{~min}$. After removal of the antibody, the immune complexes were detected by subsequent reaction with tetramethylbenzidine. The reaction was stopped by the addition of sulfuric acid, and the product was quantified by measuring the absorbance at $450 \mathrm{~nm}$.

2.5. Statistics. The data from quadruplicate cultures are presented as the mean \pm SE. Comparison between groups was performed by using one-way ANOVA, and the significance of the differences between the mean values was tested by using Fisher's PLSD test. Comparison between two groups was performed by using the Student's $t$-test. $P$ values $<0.05$ were considered statistically significant.

\section{Results}

Variable densities of AEC were seeded into 96-well plates and incubated. After $96 \mathrm{~h}$ of incubation, activin A concentrations in the media were measured. Increased activin A concentrations in the media were observed in AEC without LPS in a cell density-dependent manner, and the activin A concentrations were significantly higher at cell densities of 5,000 cells/well or higher $(P<0.05)$ (Figure 1$)$. LPS $(10 \mu \mathrm{g} / \mathrm{mL})$ significantly increased activin A concentrations at densities of 2,500 cells/well and greater $(P<0.01)$. Activin A concentrations of cell lysates from either LPS-stimulated AEC or control AEC were below assay sensitivity (data not shown). Therefore, the increase of activin A concentrations in the medium was equivalent to the increase of activin A production and secretion in AEC.

The stimulatory effects of various concentrations of LPS on activin A secretion in AEC were confirmed by three independent studies of AEC from three patients. In each experiment, a dose-dependent increase in activin A secretion from AEC occurred after $96 \mathrm{~h}$ of culture with LPS (Figure 2).

The effects of LPS on AEC proliferation were also studied. LPS $(10 \mu \mathrm{g} / \mathrm{mL})$ suppressed cell proliferation at each cell density (1,250-20,000 cells/well) (Figure 3(a)). A dosedependent inhibitory effect of LPS on AEC proliferation was also shown by three independent studies that used AEC from three patients (Figure 3(b)).

\section{Discussion}

AEC secreted activin A in a cell density-dependent manner in cultures of AEC prepared from the trypsinization of amnions from women with full-term pregnancies. This type of AEC culture has been utilized in studies of the syntheses 


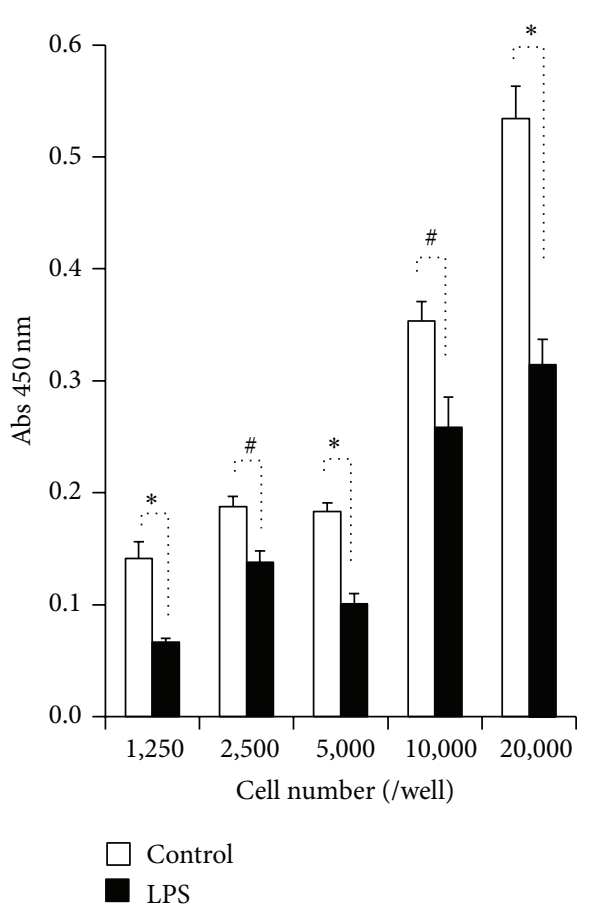

(a)

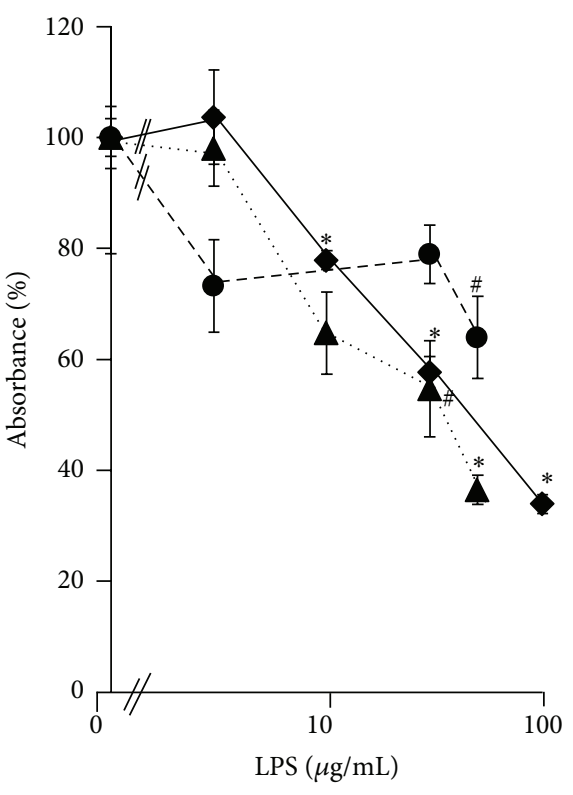

(b)

FIGURE 3: Effect of LPS on BrdU incorporation in AEC. (a) AEC were seeded in 96-well microplates at densities of 1,250, 2,500, 5,000, 10,000 , and 20,000 cells per well in $200 \mu \mathrm{L}$ of DME/Ham's F12 medium supplemented with $10 \% \mathrm{FBS}, 100 \mu \mathrm{g} / \mathrm{mL}$ streptomycin, and $0.5 \mu \mathrm{g} / \mathrm{mL}$ amphotericin B. Either LPS $(10 \mu \mathrm{g} / \mathrm{mL})$ or vehicle (control) was added to each well. After $96 \mathrm{~h}$ of culture, BrdU incorporation was studied. The results from the quadruplicate assay are shown as the mean $\pm \mathrm{SE}(n=4) .{ }^{\#} P<0.05$ compared with the control value at each cell density. ${ }^{*} P<0.01$ compared with the control value at each cell density. (b) Fetal membranes were obtained from three patients. AEC from each patient were cultured independently in DME/Ham's 12 medium supplemented with $10 \% \mathrm{FBS}, 100 \mu \mathrm{g} / \mathrm{mL}$ streptomycin, $0.5 \mu \mathrm{g} / \mathrm{mL}$ amphotericin B, and various concentrations of LPS. After $96 \mathrm{~h}$ of culture, BrdU incorporation was studied. Closed circles, closed rectangles, and closed triangles show AEC from each patient. The absorbance at AEC cultured without LPS is shown as $100 \%$. The results from the quadruplicate assay are shown as the mean \pm SE $(n=4) .{ }^{\#} P<0.05$ compared with the control (LPS; $0 \mathrm{ng} / \mathrm{mL}$ ) value. ${ }^{*} P<0.01$ compared with the control (LPS; $0 \mathrm{ng} / \mathrm{mL}$ ) value.

and secretion of phospholipids and prostaglandins [20, 21], matrix metalloproteinase- 9 and extracellular matrix metalloproteinase inducer [22, 23], brain natriuretic peptide [24], endothelin-1 [24, 25], fibronectin [26, 27], albumin and glycogen [28], and cystic fibrosis transmembrane conductance regulator [29]. Keelan et al. used this method to study activin A production by AEC [16]. The cell density and incubation time of our AEC cultures were comparable (although not identical) to the conditions used by Keelan et al.

LPS enhanced the activin A secretion at each cell density (2,500-20,000 cells/well). LPS also stimulated activin A secretion dose dependently in three independent cultures of AEC from three patients. Rosenberg et al. reported that LPS stimulated activin A release from cultured amniochorion explants but not from placental villous tissue [14]. Our study has clearly shown that LPS stimulates activin A secretion from AEC. On the other hand, Keelan et al. reported that LPS did not affect activin A production in amnion explant cultures [15]. The components of amniotic explants other than AEC might inhibit the effects of LPS, or the LPS dose used in their study $(5 \mu \mathrm{g} / \mathrm{mL})$ might not be sufficient to stimulate activin A secretion. In a mouse epithelial Sertoli cell line, the secretion of activin A is enhanced through TLR4 by LPS stimulation [8]. Since functional TLR4 is expressed in human AEC [18], future studies must determine if similar mechanisms affect activin A secretion by LPS-stimulated AEC.

LPS stimulated activin A secretion from AEC at doses of $10 \mu \mathrm{g} / \mathrm{mL}$ or higher. The endotoxin concentrations in the amniotic fluid of women with premature rupture of membranes were between several hundred $\mathrm{pg} / \mathrm{mL}$ to several $\mu \mathrm{g} / \mathrm{mL}$, as determined by the Limulus amebocyte lysate assay with E.coli LPS as the standard [30]. Compared to the endotoxin concentrations in the amniotic fluid, the LPS doses that stimulated activin A secretion from AEC were higher. On the other hand, the LPS doses used in the present study are comparable to the doses used in previous studies of human gestational tissues and cells [31-35]. Local LPS concentrations in the microenvironment of AEC must be higher than the concentrations in amniotic fluid when Gramnegative bacteria invade the amnion [36].

LPS suppressed cell proliferation. Therefore, the increase of activin A secretion is caused by enhanced production and secretion of activin A in AEC rather than an increased 
number of AEC. LPS induces apoptosis directly or indirectly in several types of cells [37-41]. Apoptosis of AEC occurs in fetal membranes from patients with chorioamnionitis [42]. The present results are in accordance with these findings. The tensile strength of fetal membranes is provided by collagens in the amnion, and the tensile strength is reduced in chorioamnionitis by the degradation of collagens by matrix metalloproteinases [43]. LPS itself might weaken the strength of membranes by suppressing AEC proliferation.

In conclusion, LPS stimulated activin A secretion from human AEC, which may be a mechanism in the pathogenesis of amnionitis.

\section{Acknowledgments}

The authors thank Ms. Junko Sakurai for her assistance. This work was supported by a Grant-in-Aid from the Japan Society for the Promotion of Science (15591729, 18591794, and 22591816).

\section{References}

[1] D. M. de Kretser, R. E. O’Hehir, C. L. Hardy, and M. P. Hedger, "The roles of activin A and its binding protein, follistatin, in inflammation and tissue repair," Molecular and Cellular Endocrinology, vol. 359, no. 1-2, pp. 101-106, 2012.

[2] S. Werner and C. Alzheimer, "Roles of activin in tissue repair, fibrosis, and inflammatory disease," Cytokine and Growth Factor Reviews, vol. 17, no. 3, pp. 157-171, 2006.

[3] D. J. Phillips, D. M. de Kretser, and M. P. Hedger, "Activin and related proteins in inflammation: not just interested bystanders," Cytokine and Growth Factor Reviews, vol. 20, no. 2, pp. 153-164, 2009.

[4] S. Ebert, R. Nau, and U. Michel, "Role of activin in bacterial infections: a potential target for immunointervention?" Immunotherapy, vol. 2, no. 5, pp. 673-684, 2010.

[5] S. Huber and C. Schramm, "Role of activin A in the induction of Foxp3+ and Foxp3- $\mathrm{CD}^{+}$regulatory T cells," Critical Reviews in Immunology, vol. 31, no. 1, pp. 53-60, 2011.

[6] M. P. Hedger, W. R. Winnall, D. J. Phillips, and D. M. de Kretser, "The regulation and functions of activin and follistatin in inflammation and immunity," Vitamins and Hormones, vol. 85, pp. 255-297, 2011.

[7] K. L. Jones, J. N. Brauman, N. P. Groome, D. M. De Kretser, and D. J. Phillips, "Activin A release into the circulation is an early event in systemic inflammation and precedes the release of follistatin," Endocrinology, vol. 141, no. 5, pp. 1905-1908, 2000.

[8] K. L. Jones, A. Mansell, S. Patella et al., "Activin A is a critical component of the inflammatory response, and its binding protein, follistatin, reduces mortality in endotoxemia," Proceedings of the National Academy of Sciences of the United States of America, vol. 104, no. 41, pp. 16239-16244, 2007.

[9] U. Michel, S. Ebert, D. Phillips, and R. Nau, "Serum concentrations of activin and follistatin are elevated and run in parallel in patients with septicemia," European Journal of Endocrinology, vol. 148, no. 5, pp. 559-564, 2003.

[10] S. Muttukrishna, P. A. Fowler, L. George, N. P. Groome, and P. G. Knight, "Changes in peripheral serum levels of total activin A during the human menstrual cycle and pregnancy," Journal of Clinical Endocrinology and Metabolism, vol. 81, no. 9, pp. 33283334, 1996.
[11] J. Rabinovici, P. C. Goldsmith, C. L. Librach, and R. B. Jaffe, "Localization and regulation of the activin-A dimer in human placental cells," Journal of Clinical Endocrinology and Metabolism, vol. 75, no. 2, pp. 571-576, 1992.

[12] F. Petraglia, M. M. Anceschi, L. Calza et al., "Inhibin and activin in human fetal membranes: evidence for a local effect on prostaglandin release," Journal of Clinical Endocrinology and Metabolism, vol. 77, no. 2, pp. 542-548, 1993.

[13] F. Petraglia, A. M. Di Blasio, P. Florio et al., "High levels of fetal membrane activin $\beta \mathrm{A}$ and activin receptor IIB mRNAs and augmented concentration of amniotic fluid activin $\mathrm{A}$ in women in term or preterm labor," Journal of Endocrinology, vol. 154, no. 1, pp. 95-101, 1997.

[14] V. A. Rosenberg, I. A. Buhimschi, A. T. Dulay et al., "Modulation of amniotic fluid activin-a and inhibin-a in women with preterm premature rupture of the membranes and infectioninduced preterm birth," American Journal of Reproductive Immunology, vol. 67, no. 2, pp. 122-131, 2012.

[15] J. A. Keelan, R. L. Zhou, L. W. Evans, N. P. Groome, and M. D. Mitchell, "Regulation of activin A, inhibin A, and follistatin production in human amnion and choriodecidual explants by inflammatory mediators," Journal of the Society for Gynecologic Investigation, vol. 7, no. 5, pp. 291-296, 2000.

[16] J. A. Keelan, N. P. Groome, and M. D. Mitchell, "Regulation of activin-A production by human amnion, decidua and placenta in vitro by pro-inflammatory cytokines," Placenta, vol. 19, no. 5-6, pp. 429-434, 1998.

[17] J. A. Keelan, R.-L. Zhou, and M. D. Mitchell, "Activin a exerts both pro- and anti-inflammatory effects on human term gestational tissues," Placenta, vol. 21, no. 1, pp. 38-43, 2000.

[18] K. M. Adams, J. Lucas, R. P. Kapur, and A. M. Stevens, "LPS induces translocation of TLR4 in amniotic epithelium," Placenta, vol. 28, no. 5-6, pp. 477-481, 2007.

[19] Y. Abe, H. Sinozaki, T. Takagi et al., "Identification of 2,3,7,8tetrachlorodibenzo-p-dioxin (TCDD)-inducible genes in human amniotic epithelial cells," Reproductive Biology and Endocrinology, vol. 4, article no. 27, 2006.

[20] J. R. Okita, N. Sagawa, M. L. Casey, and J. M. Snyder, "A comparison of human amnion tissue and amnion cells in primary culture by morphological and biochemical criteria," In Vitro, vol. 19, no. 2, pp. 117-126, 1983.

[21] K. Sun, R. Ma, X. Cui et al., "Glucocorticoids induce cytosolic phospholipase A2 and prostaglandin $\mathrm{H}$ synthase type 2 but not microsomal prostaglandin E synthase (PGES) and cytosolic PGES expression in cultured primary human amnion cells," Journal of Clinical Endocrinology and Metabolism, vol. 88, no. 11, pp. 5564-5571, 2003.

[22] W. Li and J. R. G. Challis, "Corticotropin-releasing hormone and urocortin induce secretion of matrix metalloproteinase9 (MMP-9) without change in tissue inhibitors of MMP-1 by cultured cells from human placenta and fetal membranes," Journal of Clinical Endocrinology and Metabolism, vol. 90, no. 12, pp. 6569-6574, 2005.

[23] W. Li, N. Alfaidy, and J. R. G. Challis, "Expression of extracellular matrix metalloproteinase inducer in human placenta and fetal membranes at term labor," Journal of Clinical Endocrinology and Metabolism, vol. 89, no. 6, pp. 2897-2904, 2004.

[24] H. Itoh, N. Sagawa, M. Hasegawa et al., "Brain natriuretic peptide is present in the human amniotic fluid and is secreted from amnion cells," Journal of Clinical Endocrinology and Metabolism, vol. 76, no. 4, pp. 907-911, 1993. 
[25] H. Itoh, N. Sagawa, M. Hasegawa et al., “Transforming growth factor- $\beta$ stimulates, and glucocorticoids and epidermal growth factor inhibit brain natriuretic peptide secretion from cultured human amnion cells," Journal of Clinical Endocrinology and Metabolism, vol. 79, no. 1, pp. 176-182, 1994.

[26] S. Guller, L. Kong, R. Wozniak, and C. J. Lockwood, "Reduction of extracellular matrix protein expression in human amnion epithelial cells by glucocorticoids: a potential role in preterm rupture of the fetal membranes," Journal of Clinical Endocrinology and Metabolism, vol. 80, no. 7, pp. 2244-2250, 1995.

[27] Y. Ma, C. J. Lockwood, A. L. Bunim, D. A. Giussani, P. W. Nathanielsz, and S. Guller, "Cell type-specific regulation of fetal fibronectin expression in amnion: conservation of glucocorticoid responsiveness in human and nonhuman primates," Biology of Reproduction, vol. 62, no. 6, pp. 1812-1817, 2000.

[28] S. Takashima, H. Ise, P. Zhao, T. Akaike, and T. Nikaido, "Human amniotic epithelial cells possess hepatocyte-like characteristic and functions," Cell Structure and Function, vol. 29, no. 3, pp. 73-84, 2004.

[29] S. V. Murphy, R. Lim, P. Heraud et al., "Human amnion epithelial cells induced to express functional cystic fibrosis transmembrane conductance regulator," PLoS One, vol. 7, no. 9, Article ID e46533, 2012.

[30] R. Romero, P. Roslansky, E. Oyarzun et al., "Labor and infection: II. Bacterial endotoxin in amniotic fluid and its relationship to the onset of preterm labor," American Journal of Obstetrics and Gynecology, vol. 158, no. 5, pp. 1044-1049, 1988.

[31] J. A. Keelan, T. Sato, and M. D. Mitchell, "Interleukin (IL)-6 and IL-8 production by human amnion: regulation by cytokines, growth factors, glucocorticoids, phorbol esters, and bacterial lipopolysaccharide," Biology of Reproduction, vol. 57, no. 6, pp. 1438-1444, 1997.

[32] M. Lappas, M. Permezel, H. M. Georgiou, and G. E. Rice, "Regulation of phospholipase isozymes by nuclear factorkappaB in human gestational tissues in vitro," Journal of Clinical Endocrinology and Metabolism, vol. 89, no. 5, pp. 2365-2372, 2004.

[33] M. D. Mitchell, M. C. Chang, T. Chaiworapongsa et al., "Identification of 9,11 $\alpha$-prostaglandin F2 in human amniotic fluid and characterization of its production by human gestational tissues," Journal of Clinical Endocrinology and Metabolism, vol. 90, no. 7, pp. 4244-4248, 2005.

[34] K. Y. Kim, H. K. Shin, J. M. Choi, and K. W. Hong, "Inhibition of lipopolysaccharide-induced apoptosis by cilostazol in human umbilical vein endothelial cells," Journal of Pharmacology and Experimental Therapeutics, vol. 300, no. 2, pp. 709-715, 2002

[35] J. A. Keelan, S. Khan, F. Yosaatmadja, and M. D. Mitchell, "Prevention of inflammatory activation of human gestational membranes in an ex vivo model using a pharmacological NF- $\kappa \mathrm{B}$ inhibitor," Journal of Immunology, vol. 183, no. 8, pp. 5270-5278, 2009.

[36] A. Splichalova, I. Trebichavsky, Y. Muneta, Y. Mori, and I. Splichal, "Effect of bacterial virulence on IL-18 expression in the amnion infected with Escherichia coli," American Journal of Reproductive Immunology, vol. 53, no. 5, pp. 255-260, 2005.

[37] S. J. Fortunato, R. Menon, and S. J. Lombardi, "Support for an infection-induced apoptotic pathway in human fetal membranes," American Journal of Obstetrics and Gynecology, vol. 184, no. 7, pp. 1392-1398, 2001.

[38] T. Suzuki, M. Kobayashi, K. Isatsu et al., "Mechanisms involved in apoptosis of human macrophages induced by lipopolysaccharide from Actinobacillus actinomycetemcomitans in the presence of cycloheximide," Infection and Immunity, vol. 72, no. 4, pp. 1856-1865, 2004.

[39] H. Karahashi, K. S. Michelsen, and M. Arditi, "Lipopolysaccharide-induced apoptosis in transformed bovine brain endothelial cells and human dermal microvessel endothelial cells: the role of JNK," Journal of Immunology, vol. 182, no. 11, pp. 7280-7286, 2009.

[40] Y. Zhao, G. Cui, N. Zhang, Z. Liu, W. Sun, and Q. Peng, "Lipopolysaccharide induces endothelial cell apoptosis via activation of $\mathrm{Na}_{+} / \mathrm{H}_{+}$exchanger 1 and calpain-dependent degradation of Bcl-2," Biochemical and Biophysical Research Communications, vol. 427, no. 1, pp. 125-132, 2012.

[41] J. H. Fan, G. G. Feng, L. Huang et al., "Role of naofen in apoptosis of hepatocytes induced by lipopolysaccharide through mitochondrial signaling in rats," Hepatology Research, vol. 42, no. 7, pp. 696-705, 2012.

[42] S. Kataoka, I. Furuta, H. Yamada et al., "Increased apoptosis of human fetal membranes in rupture of the membranes and chorioamnionitis," Placenta, vol. 23, no. 2-3, pp. 224-231, 2002.

[43] S. Parry and J. F. Strauss III, "Premature rupture of the fetal membranes," The New England Journal of Medicine, vol. 338, no. 10, pp. 663-670, 1998. 


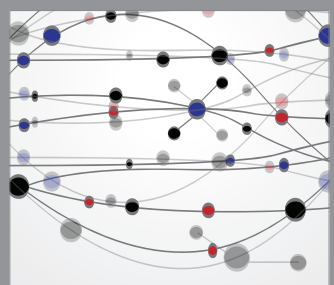

The Scientific World Journal
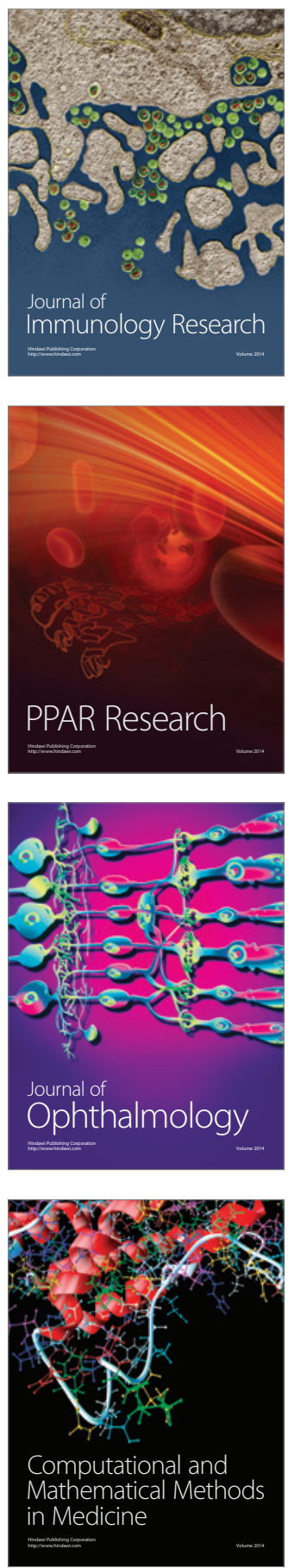

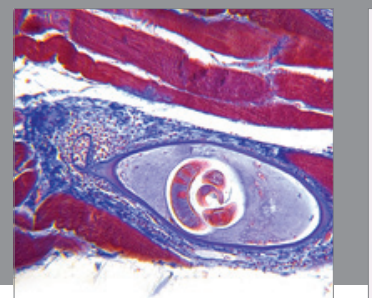

Gastroenterology

Research and Practice
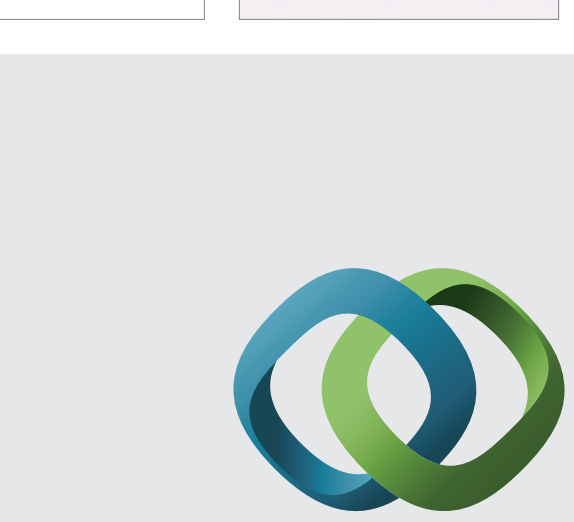

\section{Hindawi}

Submit your manuscripts at

http://www.hindawi.com
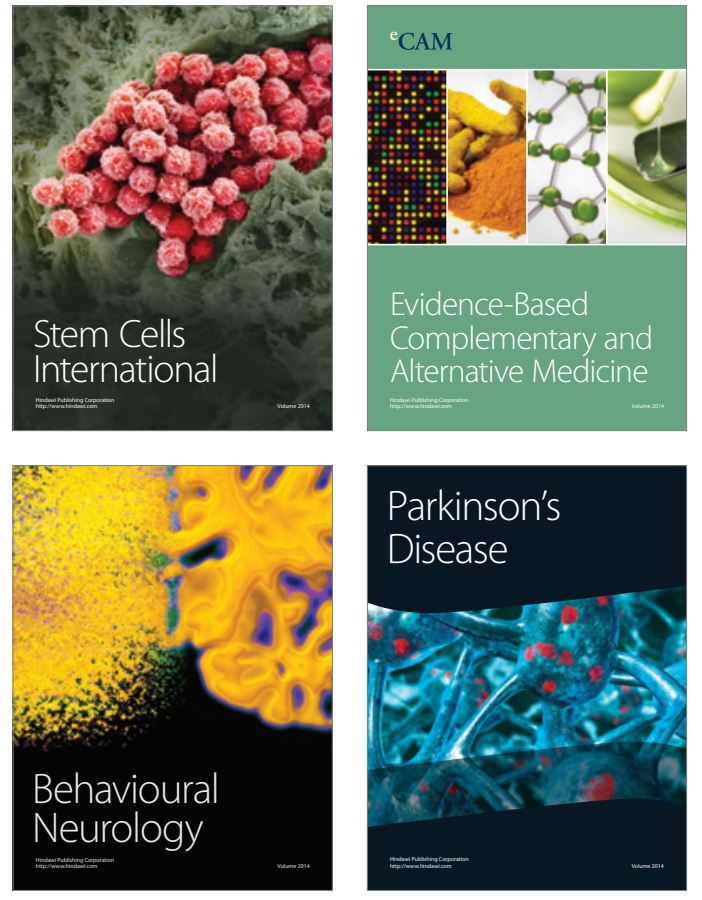
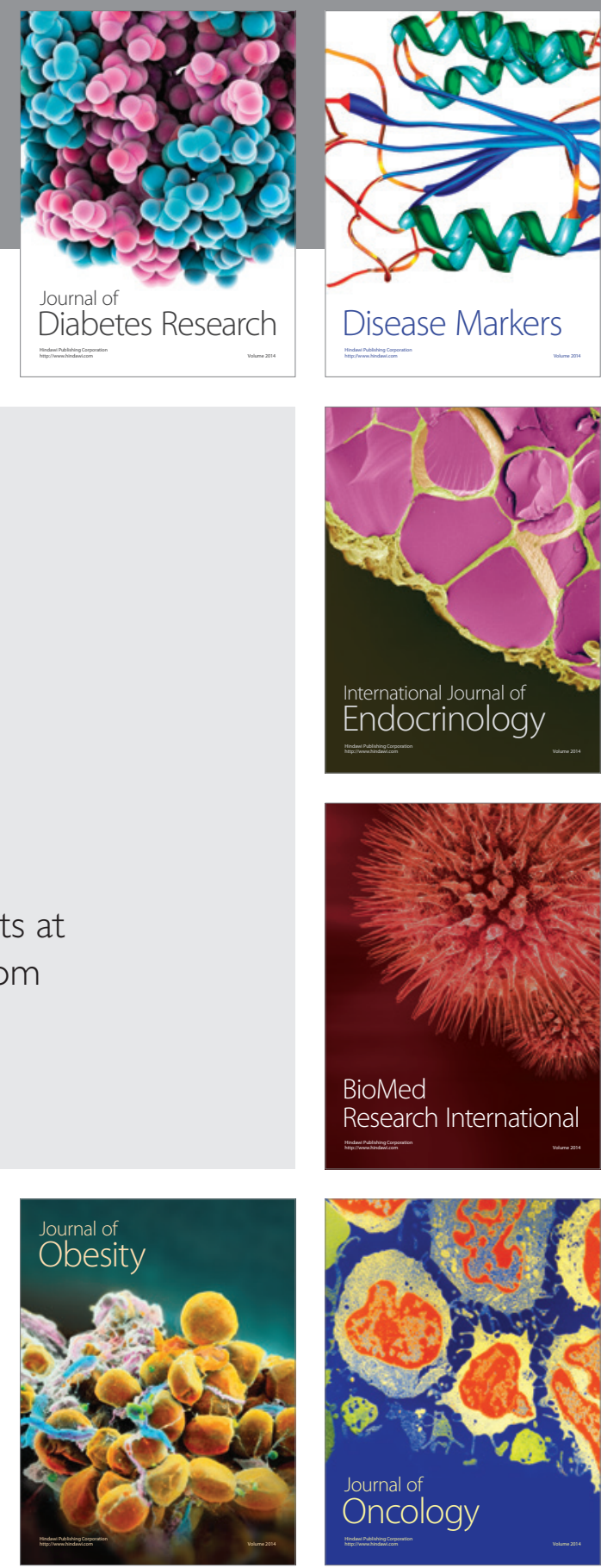

Disease Markers
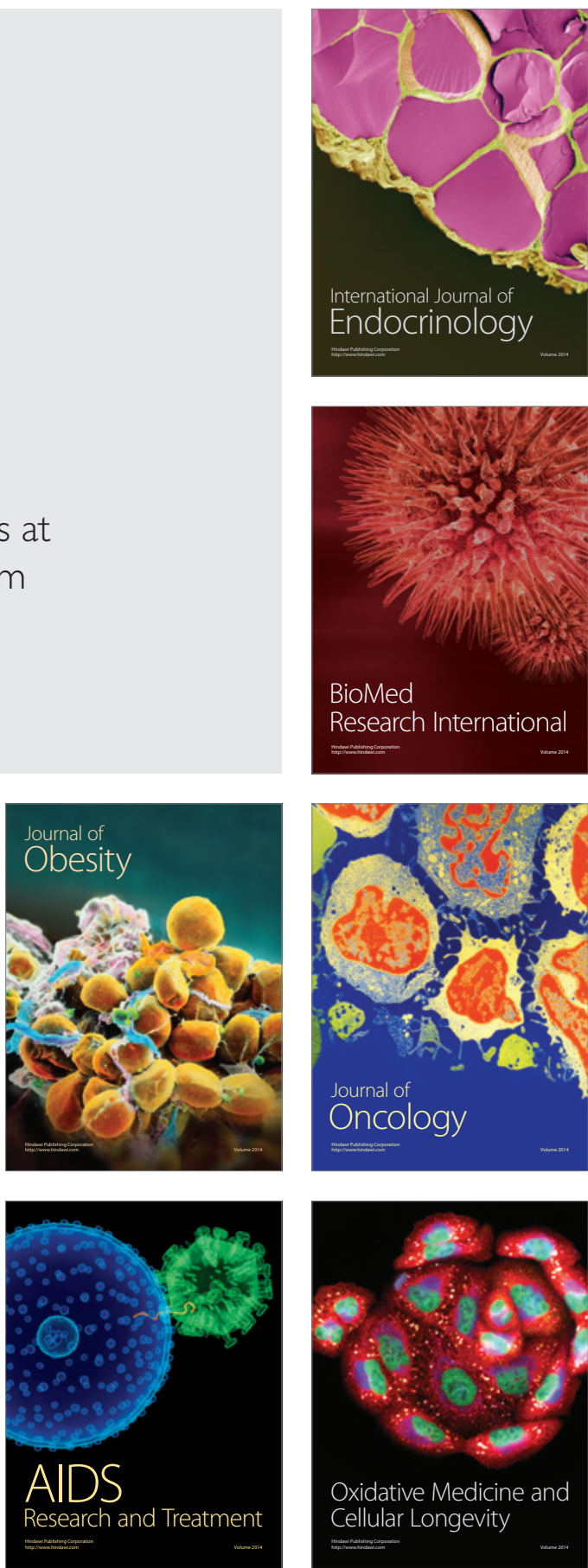